\title{
Village Development Index and ICT Infrastructure in Tourism Region
}

\author{
AR. Rohman Taufiq Hidayat ${ }^{*}$, Yanuar Eka Prasetya, Dian Dinanti \\ Department of Urban and Regional Planning, Faculty of Engineering, University of Brawijaya, Malang, Indonesia
}

\begin{abstract}
The tourism sector is one of the sectors that can be integrated with the village community empowerment, namely by utilizing the unique natural potential of the village. Tourism is one of the ways to improve the status of village development. Tourism needs technological support to develop. Sukapura District is a strategic area for the development of tourism activities and has a low level of teledensity in Probolinggo Regency. This research aimed to examine the relationship of tourism region development related to ICT and village development in Sukapura District, Probolinggo Regency. This study used village development index analysis and literature review. The results of the analysis indicated that ICT infrastructure affected village development index which was related to the geographical conditions of the Sukapura area which was far from urban centers. Telephone service has been proposed as the main strategy to overcome geographical weaknesses which were related to its use in dealing with rural problems.
\end{abstract}

Keywords: ICT Infrastructure, Tourism, Village Development Index.

\section{INTRODUCTION}

The development of rural areas by utilizing the local potential and empowering rural communities is one of the effective ways to improve the village economy. One of the sectors that can be integrated with village community empowerment is tourism, namely by utilizing the unique natural potential of the village. Tourism has proven to be a catalyst for economic growth, capital, income and worker transfer from industry, urban areas and developed areas to non-industrial areas [1].

Current tourism developments must be accompanied by the support of adequate Information and Communication Technology. ICT provides support to improve the competitiveness, efficiency, and performance of the tourism business [2]. Therefore, it is necessary to use ICT in developing tourism.

The development of information and communication technology not only concerns cities but also in rural areas, which are still rarely touched by telecommunications networks. In addition, ICT is widely applied efficiently in the form of a village telecommunications center. ICT has an important impact on community relations, local capacity building, as well as on education, agricultural systems, and also on women and youth empowerment in rural areas [3].

The existence of tourism activities and information and communication technology support has an impact on the development of

\footnotetext{
* Correspondence Address:

AR. Rohman Taufiq Hidayat

E-mail : a.r.taufiq.h@ub.ac.id

Address : Dept. Urban and Regional Planning, University of Brawijaya, MT Haryono 167, 65145, Malang.
}

rural areas. At present, village development can be measured using the Village Development Index, which is developed to strengthen efforts to achieve the development goals of the Village and Rural Areas. The Village Development Index is not only useful for knowing the development status of each village that is closely related to its characteristics, but it can also be developed as an instrument to assess the 2015-2019 RPJMN's (Regional Medium Term Development Plan) target and coordination in village development [4].

One of the Regencies that has a Village Development Index lower than the average Village Development Index of Province is Probolinggo Regency, with a value of 0.6303 [4]. This shows that there is still a need to improve and develop villages to create an independent village in Probolinggo Regency.

In Probolinggo, there are still areas that have not equipped with phone signal service, especially in the southern region of Probolinggo Regency [5]. The gap occurs between the northern and southern regions of the Probolinggo Regency. The northern region has a high level of teledensity, which has a high level of ICT service. Whereas in the southern region, the level of teledensity is still relatively low. One of the areas with the lowest teledensity level is Sukapura District.

Besides being a region with a low level of teledensity, Sukapura District is one of the strategic areas contained in the Spatial Plans of Probolinggo Regency [6]. Sukapura District is a strategic area for tourism because there is one of the seven main destinations for Indonesian 
tourism located in this area, namely Mount Bromo.

Sukapura District located in the entrance area to Mount Bromo. Based on data from Probolinggo Regency in 2018 (in figures) [7], 40\% of tourists visited Mount Bromo. In addition, there are also several other tourist attractions such as Mentigen Hill which has beautiful natural scenery, Umbulan Waterfall, Lowo Cave or unique bat cave, Seruni Tourism Village which showcases activities of Tengger tribal communities [6]. The existence of these tourism activities certainly can support the development of villages [8], especially in Sukapura District.

Based on these issues, this study examined the relevance of the issue with the Village Development Index in Sukapura District. The study examined the characteristics of the use of ICT infrastructure in Sukapura District, which was categorized as having a low level of teledensity for phone signal, even though this area located in tourism region that required ICT Infrastructure support. The two will be reviewed by linking the Village Development Index in each village.

\section{MATERIAL AND METHOD}

This study used the Village Development Index calculation as well as literature studies, which included collecting data from related agencies, as well as reviewing theories from existing journals so that a descriptive analysis obtained. The Village Development Index (VDI) used data sourced from Village Potential, which was compiled by the Central Bureau of Statistics. VDI is a composite index consisting of social, economic, and cultural Security indices that represent the sustainability dimension [4],[8]. The three indices had a variable, and each variable was derived into 52 indicators. Here is how to calculate the Village Development Index [4]:

a. Every variable followed by an indicator. Number indicator in every variable is vary. Each indicator has five options with an ordinal scale.

b. A value is given to each indicator between 1 to 5 . The higher the score, the better the condition.

c. Village achievement's value was calculated by summing up all indicators value in every variables. Then, calculating the value of all variables in every dimension (social, economic, and ecology, Table 1). Calculating each index using the following formula:

$$
\text { Index }=\frac{\Sigma \text { Indicator } X}{\text { Maximum Value }(X)}
$$

Indicator value represents the current village condition. The maximum value represents the highest value of the indicator that the village aims to. This equation can solve an unequal number of variables in every dimension.

d. Calculating the Village Development Index using the following formula:

$$
\mathrm{VDI}=1 / 3(\mathrm{SSI}+\mathrm{ESI}+\mathrm{EVSI})
$$

Description:

VDI : Village Development Index

SSI : Social Security Index

ESI : Economic Security Index

EVSI :Environmental Security Index (Ecology)

\begin{tabular}{|c|c|c|}
\hline $\begin{array}{c}\text { Dimension } \\
\text { indices }\end{array}$ & & Variables \\
\hline \multirow{4}{*}{ 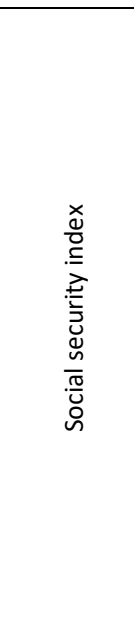 } & Health & $\begin{array}{l}\text { Health facility } \\
\text { Community health } \\
\text { empowerment } \\
\text { Health insurance }\end{array}$ \\
\hline & Education & $\begin{array}{l}\text { Access to elementary } \\
\text { education } \\
\text { Access to informal } \\
\text { education } \\
\text { Access to community } \\
\text { library }\end{array}$ \\
\hline & Social capital & $\begin{array}{l}\text { Social solidarity } \\
\text { Tolerance } \\
\text { Security } \\
\text { Social welfare }\end{array}$ \\
\hline & Settlement & $\begin{array}{l}\text { Access to clean water } \\
\text { Sanitation } \\
\text { Electricity } \\
\text { ICT }\end{array}$ \\
\hline 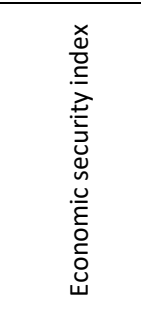 & Economic & $\begin{array}{l}\text { Community products } \\
\text { Commercial center } \\
\text { Access to distribution and } \\
\text { logistic services } \\
\text { Access to credit and } \\
\text { financial institutions } \\
\text { Availability of community } \\
\text { financial institution } \\
\text { Regional openness }\end{array}$ \\
\hline 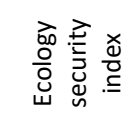 & Ecology & $\begin{array}{l}\text { Environmental quality } \\
\text { Natural disaster prone }\end{array}$ \\
\hline
\end{tabular}

Table 1. Research variables

e. Classifying composite index values into one of the Village status using the following guidelines:

- Very Disdvantaged Village $(<0.491)$;

- Disadvantaged Village $(>0.491-<0.599)$;

- Developing Village ( $>0.599-<0.707)$;

- Developed Village ( $>0.707-<0.815)$;

- and Independent Village (>0.81) 
This study examined the Village Development Index in villages in Sukapura District. This study then descriptively discussed ICT with VDI towards tourism development with a literature review approach. In this study, ICT variables included the number of telephone connections, number of households with internet access, number of BTS, number of households with radio, and number of households with television.

\section{Data Collection}

This study used data derived from primary and secondary surveys. A primary survey was conducted using unstructured observation and interview techniques related to tourism development variables and infrastructure conditions. Respondents of this research were 12 village chiefs. They have the capability and knowledge regarding tourism and infrastructure development issues. Data collection for VDI and ICT variables used secondary data sourced from government documents. While the relationship of VDI, ICT infrastructure, and tourism using secondary data sourced from the literature.

\section{Village Development Index}

Village Development Index [4],[8] (Ministry of Village, Development of Disadvantaged Regions and Transmigration, 2015 and 2016) classified villages in five (5) status, namely: (i) Very Disadvantaged Village; (ii) Disadvantaged Village; (iii) Developing Village; (iv) Developed Village; and (v) Independent Village. The classification is aimed to show the level of the development status of each village in the range of scores of $0.27-0.92$.

The classification in the five village statuses is also aimed to sharpen the determination of the status of village development, and at the same time, recommend the necessary policy interventions. Dealing with Very Disadvantaged Villages will differ in the level of affirmation of their policies compared to Disadvantaged Villages. Developing Village related to the situation and conditions in the status of Disadvantaged Villages and Very Disadvantaged Villages can be explained by vulnerability factors.

If there is pressure on vulnerability factors, such as the occurrence of economic shocks, natural disasters, or social conflicts, it will make the status of developing villages fall to disadvantaged villages. And usually, if a natural disaster factor dealt without rapid and appropriate handling, or a prolonged social conflict occurs, it has the potential to make the Disadvantaged Villages to fall to Very Disadvantaged Villages.

Meanwhile, the ability of the Developing Villages to manage power, especially related to potential, information/value, innovation/ initiative, and entrepreneurship, will support the progress of the Developing Villages into Developed Villages. The classification of village status based on the Village Development Index also directed at strengthening efforts to facilitate the promotion of the Villages towards Independent Villages.

VDI employed a sustainable development concept that consists of social, economy, and ecology. Those explained into variables and indicators. Equity in this context only considers social and economic dimensions. According to the three E's sustainability theory, equity affects ecology and economy. This concept ensures that development is beneficial in economic, social, and ecological aspects at the same time [8].

VDI compilation has 2 main objectives [4],[8]. First is the determination of the status of progress and autonomy. Second, VDI aims to provide basic village data and information. Based on these two objectives, village development oriented towards increasing VDI. VDI is composed of 3 indices, namely social, economic, and ecological Security. The three indices have 22 variables, where the variables explained in 52 indicators.

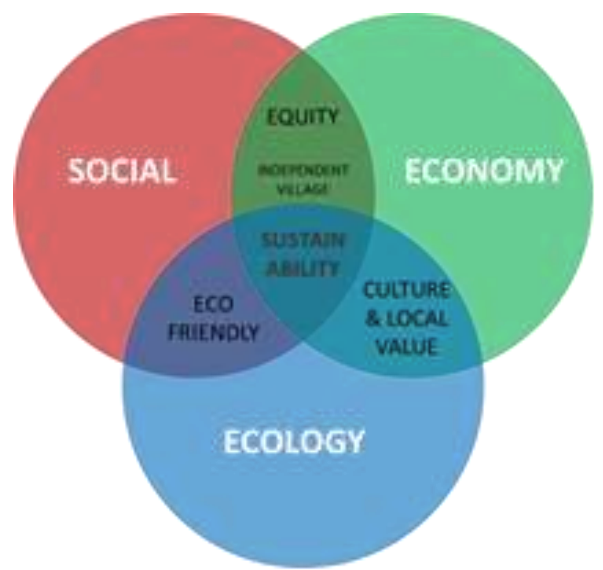

Figure 1. Dimension of Village Development Index (VDI) [4][8]

\section{ICT infrastructure}

People often misunderstand ICT. Often, ICT always connected with things related to computers and the internet. ICT is covering all technologies related to tools for communication, both electronic and non-electronic. ICT is 
generally grouped based on the duration of the ICT used. Greenberg [10] divided ICT into 3 categories, namely new ICT (e.g. computers, satellites, wireless communication, internet, email, and multimedia); old ICT (e.g radio, television, telegraph and telephone); very old ICT (newspapers, books and letters).

Currently, new ICT dominates the use of ICT. ICT users take advantage of the progress of the internet and technology to communicate. For example, there is social media use on mobile phones. The development of ICT requires a qualified infrastructure. New ICT is no longer dependent on cables, but on wireless networks, namely BTS and satellite connections. Wireless networks are very suitable for Indonesia, which has geographical challenges. Therefore, the development of the cable telephone network has not experienced a high increase.

The internet as one of the ICTs uses both wired and wireless networks. Due to the increasing quality and quantity of wireless networks, internet users prefer to use mobile phones rather than computers. The use of mobile phones has an impact on the way people communicate.

\section{Relationship between ICT Infrastructure and Tourism}

The synergistic relationship between information and communication technology (ICT) and tourism in recent times has brought necessary changes in the tourism industry in a growing and increasingly developing context [11]. ICT has reformed the entire process of developing tourism services, management and marketing, and the entire tourism industry [12]. With the impact of increasing the efficiency and effectiveness of tourism companies, ICT can be seen as a fundamental part of the tourism business's modernity [13]. The tourism industry has undergone several important changes to innovative developments brought about by ICT [14].

ICT has gradually produced a paradigm shift, changed the structure of the tourism industry, and developed various opportunities and threats in the tourism industry [13]. ICT provides a powerful tool to bring benefits to the promotion and strengthening of the tourism industry in the form of strategy and operations in general [15]. As a result, the use of ICT in the tourism industry cannot be underestimated because ICT becomes an important driving force in society today [16].

\section{Relationship between ICT Infrastructure, Tourism and Village Development}

ICT provides social-economic, socialpsychology, and socio-cultural benefits to its users [17]. From the socio-economic aspect, ICT provides opportunities and benefits in the welfare of rural communities. On the socialpsychological aspect, ICT can increase prestige (pride) for the region. Increasing the closeness of the relationship between families and neighbors is a benefit of ICT. The situation and atmosphere of the village are synonymous with silence. ICT supports the mobility of the population to access the region more easily so that there is crowded traffic in the rural areas.

The influence of ICT in these 3 aspects [17] have a relationship with the Village Development Index. In VDI, there are indicators related to ICT, namely the villagers have cellular phones and strong signals; there are local, national and foreign television broadcasts; and there is internet access. Thus, ICT and village development cannot be separated.

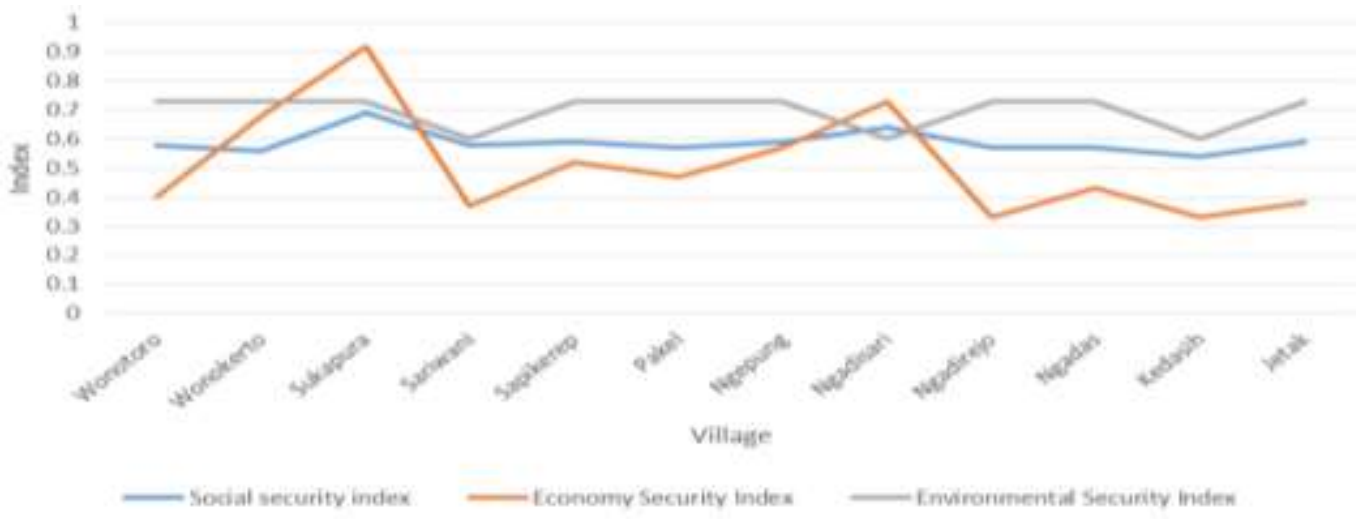

Figure 2. Economic, Social, and Environmental Security Index of Sukapura District 


\section{RESULT AND DISCUSSION \\ Overview of Sukapura District}

Sukapura District in Probolinggo Regency has an area of $102.08 \mathrm{~km}^{2}$. This district is located in the southern part of the region at the foot of the Tengger mountain range and is 33 kilometers away from the capital city of Probolinggo Regency. Sukapura District located on the slopes of the Tengger Mountain, which is famous for Mount Bromo with an altitude between 6501800 meters above sea level. The land of Sukapura District contains minerals that originate from volcanic eruptions in the form of sand and stone, mud mixed with gray clay, the nature of this kind of soil has a high fertility rate, so it is suitable if planted with vegetables and horticulture.

The composition of the population in Sukapura District as in other regions in Indonesia has a greater female population than the male population. The population of women is 10,347 and the population of men is 10,055 , with a sex ratio of 103.

For transportation facilities, most of the existing roads can be passed by four-wheeled vehicles even though there are still many roads from the Sukapura District area that built without road pavement. At present, all villages can receive mobile phone signals even though there are also villages where the signal reception is very low/bad.

\section{Village Development Index of Sukapura District}

The average value of the Social Security Index in Sukapura District is 0.59 . It means that the Average Value of the Social Security Index in Sukapura District is at the disadvantaged level. Six villages have a Social Security Index below the average, with the lowest score of 0.54 , namely Kedasih Village. The highest Social Security Index in Sukapura District is in Sukapura Village because there are junior and senior high school education facilities, and health facilities in the form of Puskesmas (Community Health Center) and post office facilities in this village.

The average value of the Economic Security Index in Sukapura District is 0.51. It means that the Average Value of the Economic Security Index in Sukapura District is at the disadvantaged level. The highest Economic Security Index in Sukapura District is in Sukapura Village because there is a District capital with economic facilities in the form of markets, shops, and banking in this village. The lowest Economic Security Index is in Ngadirejo and Kedasih Villages with a value of
0.33 , because there are no economic facilities and the location is very far from the cities.

The average value of the Environmental Security Index in Sukapura District is 0.70. Even though it located in an area that prone to volcanic disasters, adaptation and mitigation efforts in Sukapura District already exist so that the value of the Environmental Security Index in the Sukapura District classified at the developed level.

\section{Characteristics of ICT Infrastructure Services in Sukapura District \\ Telephone Service}

Based on ICT Indicator Infographics [17], current telephone use in Indonesia has a service level of $4.5 \%$ with the characteristics of use in urban areas at $8.5 \%$, while in rural areas only at $1.4 \%$. Sukapura District has the characteristics of a rural area. In Sukapura District, Telephone Service Characteristics tend to spread with almost every village having a telephone network. The level of telephone service in Sukapura District is $3.3 \%$, with the highest level of service being in Ngadisari village. Based on the average telephone service in rural areas in Indonesia, Sukapura District is in line with a higher level of service compared to the level of service in Indonesia. Sukapura Village is the center of activity in the Sukapura District so that the existing infrastructure facilities centered on Sukapura Village. It needs to be supported by the existence of telephone networks as a form of service to the community. Nevertheless, the highest level of service is in the village of Ngadisari, which is a tourism region of Mount Bromo.

It is related to land use in the form of Guest Houses and inns, which then equipped with facilities such as telephone networks. Telephone network services in Sukapura are not only supporting activities at the activity center but also in the tourism region as a form of supporting tourism activities.

Wireless telephones, also known as cellphones, are experiencing the fastest development compared to fixed-line telephones. The use of mobile phones in the Sukapura District is higher than cable telephones. BTS in Sukapura District supports the use of mobile phones even though the range of services is still limited and experiences geographical challenges. Each household has at least a cellphone. Even junior high school students have cellphones. So the number of uses and ownership of cable phones is 
very small. Village communities use more wired networks to connect to the internet.

Mobile phones provide better flexibility and economic value than wired telephones. Tourism visitors use mobile phones to record tourism attractions. Moreover, the use of mobile phones with internet facilities is increasingly widespread.

\section{Internet Service}

The level of internet service in Sukapura District is $1.1 \%$. In Sukapura District, there are only 2 villages, namely Ngadisari Village, with 12 networks and Sukapura Village, with 56 networks. The characteristics of the two villages are Sukapura Village as a District center and trade and public services, whereas Ngadisari Village is a Mount Bromo tourism village so that both villages have an internet network that is used to support its service functions.

Based on ICT Indicator Infographics [17], internet usage in Indonesia currently has a service level of $7.8 \%$ with the characteristics of use in urban areas at $14.3 \%$, while in rural areas it only reaches $7.4 \%$. In Sukapura District, the level of service available still does not meet the average internet service due to the limited number of networks and geographical difficulties. There is a need for other ICT infrastructure in line with the absence of the internet which is constrained by geographical and installation problems.

In addition, geographical location and transmission distance affect the stability of the internet connection [19]. Sukapura District located in a mountainous location that is far from the urban center so that the internet is very limited and can only be used to support tourism activities.
Internet service in Sukapura District relies on wired and wireless networks. Cable networks only enjoyed by residents. Tourists can enjoy wired internet at public or private accommodation. Although wired internet is available, almost all tourists use wireless internet. In fact, most residents of the Sukapura District use wireless internet service. Therefore, the existence of BTS and signal quality is very necessary. Moreover, the use of social media by tourists and the community is very high.

The use of the internet for social media can encourage the development of tourism [19][20]. Tourism managers and the public can use social media as a means of promotion. Tourists use social media as a means of self-actualization. Indirectly, the use of social media by tourists can be a means of tourism promotion.

\section{BTS Service}

Towers in Sukapura District installed along Local Roads. The results of plotting existing towers in Sukapura District, ten towers are in a medium-density residential area. The tower distribution only found in two villages, Sukapura Village, with six towers and Ngadisari Village, with four towers. In addition to the two villages, there are no BTS towers, which makes Sukapura District has a low level of teledensity.

The condition of BTS service in Sukapura District is currently not evenly distributed. BTS services are only located in Sukapura and Ngadisari Villages, this causes the level of teledensity in Sukapura District to be relatively low because there are still many locations that have no signal service. It also relates to the geographical condition of the steep area so that it does not meet the requirements in the BTS installation process.

Table 2. Comparison of ICT Infrastructure Services and Village Development Index of Sukapura District

\begin{tabular}{lrrrrrcc}
\hline Village & Telephone & Internet & BTS & TV & Radio & VDI & Status \\
\hline Wonotoro & $0.16 \%$ & $0.00 \%$ & $0.00 \%$ & $2.65 \%$ & $0.35 \%$ & 0.57 & Disadvantaged \\
Wonokerto & $0.14 \%$ & $0.00 \%$ & $0.00 \%$ & $5.80 \%$ & $1.14 \%$ & 0.66 & Developing \\
Sukapura & $1.49 \%$ & $0.89 \%$ & $60.00 \%$ & $16.56 \%$ & $2.03 \%$ & 0.78 & Developed \\
Sariwani & $0.00 \%$ & $0.00 \%$ & $0.00 \%$ & $4.80 \%$ & $1.53 \%$ & 0.51 & Disadvantaged \\
Sapikerep & $0.14 \%$ & $0.00 \%$ & $0.00 \%$ & $11.48 \%$ & $1.32 \%$ & 0.61 & Developing \\
Pakel & $0.00 \%$ & $0.00 \%$ & $0.00 \%$ & $4.67 \%$ & $0.81 \%$ & 0.59 & Developing \\
Ngepung & $0.22 \%$ & $0.00 \%$ & $0.00 \%$ & $7.22 \%$ & $4.71 \%$ & 0.63 & Developing \\
Ngadisari & $0.89 \%$ & $0.19 \%$ & $40.00 \%$ & $6.31 \%$ & $2.24 \%$ & 0.66 & Developing \\
Ngadirejo & $0.00 \%$ & $0.00 \%$ & $0.00 \%$ & $5.96 \%$ & $2.38 \%$ & 0.55 & Disadvantaged \\
Ngadas & $0.17 \%$ & $0.00 \%$ & $0.00 \%$ & $2.97 \%$ & $0.68 \%$ & 0.58 & Disadvantaged \\
Kedasih & $0.00 \%$ & $0.00 \%$ & $0.00 \%$ & $3.59 \%$ & $0.68 \%$ & 0.49 & Very Disadvantaged \\
Jetak & $0.00 \%$ & $0.00 \%$ & $0.00 \%$ & $2.58 \%$ & $0.35 \%$ & 0.57 & Disadvantaged \\
\hline
\end{tabular}


One of the things that need to be considered in the process of building BTS is the topography of a region, this is related to towers that are able to work optimally [21]. Sukapura District has a mountainous topography with many hills and valleys, this has an impact on the technical planning of BTS development. In Sukapura District, the requirements for establishment are certainly more difficult because of the uneven topography, which influences the number of BTSs built based on flat topography, namely Sukapura and Ngadisari villages, because in other villages the location tends to be hilly and there are also many valleys that do not allow BTS towers.

\section{Television and Radio Service}

There is a TV connection in all villages in Sukapura District, even though it located in a mountainous area. The most uses are in Sukapura villag, which has 1042 TV connections while the least number is in Jetak Village, which has 162 units.

In terms of achievement of ICT indicators for Television Services, Indonesia has a service level reaching $87.7 \%$ with characteristics of use in urban areas amounting to $94.2 \%$ while in rural areas only reaches $82.6 \%$ [17]. In Sukapura District, the level of service available still does not meet the average television service available.

The level of television service in Sukapura District is $74.6 \%$, with each village serving more than half of the total number of households. Television in Sukapura District serves every village, which then acts as a substitute for ICT Infrastructures such as the Internet, BTS, and Telephone, which has geographical aspects. Television can be accessed by every household in Sukapura District, even though there are geographical constraints, due to the existence of technology, which is in the form of a satellite dish, which then helps in terms of access to television. It can be used as an input in the development of other ICT infrastructure, namely in the form of technology and innovation, so that access to each ICT infrastructure can be achieved, even though there are obstacles in the form of geographical location constraints.

\section{Effect of ICT Infrastructure on Tourism Development}

The telephone service system stated as the main strategy to overcome geographical weaknesses, which is related to its use in addressing rural problems [22]. It is related to the distance of the District to the regency/city center. Sukapura District has a great distance to the regency/city center but has a large number of telephone lines. It proves that telephone service can be a strategy in overcoming problems of distance and accessibility in Sukapura District. It is also according to Johnson's opinion [23], which stated that instead of direct or face to face communication, telecommunications encourages decentralization from cities to suburbs and rural areas.

Telecommunications development has a special impact on location selection for businesses [23]. Customers from regional operating companies may buy shares of telephone companies that provide their services than other telephone companies [24]. With regard to business, there is Mount Bromo Tourism in the Sukapura District area, which has an impact on the surrounding economy, including the provision of accommodation services. Accounting services such as travel and lodging certainly require telephone connections to facilitate service.

For tourism business actors, the internet provides big benefits. Innkeepers use the internet as a promotional medium. Even tourists who have stayed contributed to their posts on the social media pages they have or spread information through their communication tools. Jeep rental car owners use ICT in the same way. They use SMS and chat to communicate with potential customers. They even met for the first time when consumers came to the jeep owner's place for a tour.

Sukapura District is a strategic tourism region. Therefore, many tourists visit the location, especially to Mount Bromo. However, most tourists only visit Mount Bromo. Tourists only visit a small part of the tourist attraction that is on the area.

For creative people, farming activities can become a tourist attraction. Village communities in Sukapura District can make agricultural-based tours to attract tourists visiting Mount Bromo, for example, agricultural education tours such as in Lembang Village of Bandung Regency, and picking fruit like in Gubukklakah Village of Malang Regency. The attraction is an option for tourists visiting Sukapura District.

ICT, through online promotion, provides opportunities for new tourist attractions to develop. Because of the importance and benefits of ICT, ICT infrastructure support needs to be added. With the existence of a better ICT infrastructure, all parts of Mount Bromo tourism 
region can be served so that visitors interested and visit the location.

The ICT infrastructure is not only for tourists. For the community, ICT can encourage to increase knowledge and economic welfare. ICT provides an opportunity for users to get information, especially information about prices and development of agriculture in accordance with the livelihoods of the residents of Sukapura District.

ICT provides an opportunity for farmers to get economic benefits from farming activities. Because at this time, they are very dependent on the existence of wholesalers. The existence of wholesalers is not completely wrong because they provide an opportunity for farmers to sell their crops. However, wholesalers intentionaly determine price according to their perspective rather than a market mechanism. Farmers do not have other options in selling crops. With the existence of ICT, farmers can access markets and buyers directly, so that they can strengthen their bargaining position when dealing with wholesalers.

Improving the economic condition of the community affects village development. The community has the financial power to access several public services outside the village, for example, Puskesmas (Community Health Center), High Schools, and Hospitals. Therefore, the effect of the absence of these facilities in the village can be reduced because the construction of these facilities is uncertain due to the limited financing of village development. It allows the VDI status to be low, but the welfare status experiences an increase. It becomes capital for rural communities to improve the conditions of the village and VDI independently.

Almost along the main road, there are stalls that sell people's needs. With the ease of transportation routes to the village, it is used by several residents who offer services in the form of motorbike taxi drivers so that the community can empower motorized vehicles owned to get income in meeting their needs.

\section{CONCLUSION}

The ICT infrastructure influences the value of the village development index, such as telephone network services (fixed-line and cellphone, that use BTS infrastructure). It is related to the geographical conditions of the Sukapura area. which is far from urban centers, telephone service has been proposed as the main strategy to overcome geographical weaknesses, which is related to its use in dealing with rural problems.

ICT has a significant influence on the development of villages in the Sukapura District related to the provision of tourist services and accommodation. Accommodation services such as travel and lodging certainly require telephone and internet connection to facilitate service. In addition, limitations in terms of geographical problems also cause other ICT infrastructure installations such as BTS cannot be carried out even though its' coverage area is wide enough to reach remote areas.

Villagers can utilize ICT availability to gain better social and economic conditions. Such as using the internet to promote their products. It leads to a better livelihood. As an effect, they can access facilities outside the villages, such as health facilities (e.g. Hospital).

\section{REFERENCES}

[1] Lane, B. 1994. Sustainable rural tourism strategies: a tool for development and conservation. Journal of Sustainable Tourism 2(1), 102-111.

[2] Berné, C., M. García-González, M. E. GarcíaUceda and J. M. Múgica. 2015. The effect of ICT on relationship enhancement and performance in tourism channels. Tourism Management 48, 188-198.

[3] World Bank. 2005. Information and communication technologies for rural development Volume II: an evaluation of telecenters in Indonesia. Available at: http://documents.worldbank.org/curated/e n/428521468044102261/pdf/335030v20IN D0w1verOP09151401PUBLIC1.pdf

[4] Indonesian Ministry of Village, Development of Disadvantaged Regions and Transmigration. 2015. Village Development Index. Ministry of Village, Development of Disadvantaged Regions and Transmigration. Jakarta.

[5] Office of Regional Development, Probolinggo Regency. 2015. Cell Plan Kabupaten Probolinggo. Probolinggo.

[6] Government of Probolinggo Regency. 2011. Regional Regulation No. 3 in 2011 about Spatial Plan for Probolinggo Regency. Probolinggo.

[7] Central Bureau of Statistics, Probolinggo Regency. 2018. Probolinggo Regency in figures. Probolinggo. 
[8] Parmawati, R. 2018. Ecology, Economy, Equity: sebuah upaya pengembangan ekologi dan ekonomi. UB Press. Malang.

[9] Indonesian Ministry of Village, Development of Disadvantaged Regions and Transmigration. 2016. Regulation of Indonesian Ministry of Village, Development of Disadvantaged Regions and Transmigration No. 2 in 2016 about Village Development Index. Jakarta.

[10] Greenberg, A. 2005. ICTs for poverty alleviation: basic tool and enabling sector. P.-E. Tröften. Sida.

[11] Leung, D., R. Law, H. van Hoof and D. Buhalis. 2013. Social media in tourism and hospitality: a literature review. Journal of Travel and Tourism Marketing 30, 3-22.

[12] Opara, J. A. and L. E. Onyije. 2016. Information and Communication Technologies (ICT): a panacea to achieving effective goals in institutional administration. International Journal of Management Sciences 1(1), 11-15.

[13] Stiakakis, E. and C. K. Georgiadis. 2011. Drivers of a tourism E-business strategy: the impact of information and communication technologies. Operational Research - An International Journal 11(2), 149-169.

[14] Mihalic, T. and D. Buhalis. 2013. ICT as a new competitive advantage factor-case of small transitional hotel sector. Economic and Business Review 15(1), 33-56.

[15] Aghaei, S., M. A. Nematbakhsh and H. K. Farsani. 2012. Evolution of the World Wide Web: from Web 1.0 to Web 4.0. International Journal of Web and Semantic Technology 3(1), 1-10.

[16] Paraskevas, A. 2005. The impact of technological innovation in managing global value chains in the tourism industry. In: OECD Conference on Global Tourism Growth: A Challenge for SMEs. Gwangju. 117

[17] Supriadi, D. 1992. Studi tentang profil pelanggan dan manfaat sosial-ekonomi telekomunikasi pedesaan. PT. Telekomunikasi Indonesia. Jakarta.

[18] Indonesian Ministry of Communication and Informatics. 2016. Buku Infografis Indikator TIK. Ministry of Communication and Informatics. Jakarta.

[19] Hao-Jing, S., D. Ding, H. Ling-Jin and M. YaKun. 2013. The Effect of AS's geographic locations on internet's stability. Proceedings of the $2^{\text {nd }}$ International Conference On Systems Engineering and Modeling (ICSEM13). Atlantis Press. Paris.

[20] Zeng, B. and R.Gerritsen. 2014. What do we know about social media in tourism? a review. Tourism Management Perspectives 10, 27-36.

[21] Ismail, N., M. Maharoni and I. Lindra. 2015. Analisis perencanaan pembangunan BTS (Base Transceiver Station) berdasarkan faktor kelengkungan bumi dan daerah fresnel di regional project Sumatera bagian selatan. Jurnal Kajian Islam, Sains, dan Teknologi 9(1), 104-121.

[22] Cook, E., G. Randhawa, A. Guppy, A. Chater, D. Pang and S. Large. 2016. The impact of location of the uptake of telephone based healthcare: a UK case study. International Journal of Emerging Technology and Advanced Engineering 6(6), 39-47.

[23] Johnson, L. L. 1991. Advances in telecommunications technologies that may affect the location of business activity. RAND. Santa Monica.

[24] Huberman, G. 2001. Familiarity breeds investment. The Review of Financial Studies 14(3), 659-680. 